
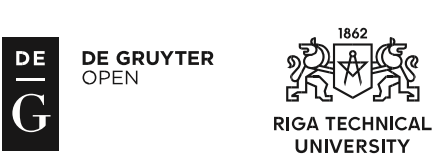

ISSN 2256-0394 (online)

ISSN 2256-0386 (print)

April 2017, 30, 51-61

doi: 10.1515/eb-2017-0005

https://www.degruyter.com/view/j/eb

\title{
REVEALING EMPLOYER'S NAME IN SOCIAL NETWORKS
}

\author{
Tom SANDER ${ }^{1}$, Ieva PŪĶE ${ }^{2}$, Biruta SLOKA ${ }^{3}$ \\ ${ }^{1}$ University of Ludwigshafen, Germany \\ ${ }^{2,3}$ University of Latvia, Latvia \\ Corresponding authore-mail: tomsander@hotmail.de
}

\begin{abstract}
The research investigates the question of the importance of mentioning the name of the employer in online and offline social networks. The exchange of information is an important part of social networks and social capital theory. Companies can use the networks of their employees to recruit new hires and to check habits and interests of likely new employees. To do that, the employee has to mention the name of the company in these social networks. The paper compares different real social networks used by family and friends and private and business social network sites (SNSs) as online social networks and compares the differences between men and women. The empirical research has been done by a survey. The survey data are analysed using the main indicators of descriptive statistics, frequency, t-test and cross tables. The results of the research reveal that real social networks are more accepted than virtual social networks. The difference in use of social networks between genders is confirmed.
\end{abstract}

Keywords: Social networks, human resource management, social network sites, virtual profiles.

\section{INTRODUCTION}

Social networks are an important part of society. Almost everybody is a member of a social network and uses networks to exchange information and resources. Social network can be very useful to identify employment opportunities or to exchange employment relevant information (McDonald, Lin \&Ao, 2009; Granovetter, 1995). Technical changes create new opportunities to share information and resources. Social networks influence our daily life and a membership in a social network can provide support, e.g. to identify employment (Granovetter, 1995). Social media is used by $70 \%$ of human resources departments to determine candidates (Weitzel et al., 2014). This support can be used to be successful and explains the importance of social networks for individuals.

Individuals use their social networks to transfer information to other persons. They are communicating information with the support of social networks. Social networks are different, and they have different characters, opportunities, purposes and tasks (Sander, Sloka \& Pauzuoliene, 2015; Caers \& Castelyns, 2011). The research investigates the differences between online and offline social networks under consideration of the exchange of employment relevant information. Online social networks are divided into business and private SNSs. Private SNSs are mainly used for leisure time; their usage rate by population in Germany is $64 \%$ and $59 \%$ in Latvia (Research by digital agency "Click", 2012). Business social 
networks are used for business purposes - usage rate in Germany is $11 \%$ (German Bureau of Statistics Report, 2015). Companies use social networks to transfer and distribute information about innovations or products but the distributed information is controlled by the marketing department of the respective company. It has been found that the use of SNSs for human resource functions helps in building employer's branding and is beneficial for attracting the right talent for the firms (Collins \& Stevens, 2002; Davison, Maraist \& Bing, 2011). Employer branding represents a firm's efforts to promote, both within and outside the firm, a clear view of what makes it different and desirable as an employer (Backhaus \& Tikoo, 2004). Many companies do not have explicit strategies for employer branding in SNSs. However, if companies expertly follow the strategies for building and maintaining SNS presence, they could reach their target groups even more efficiently (Brecht et al., 2011). The question is whether individuals would mention their employer in their social networks to create the benefit for the employer and voluntarily become part of the employer branding.

The paper concentrates on the exchange of employer's name in social networks. The research goal is to investigate in which social network individuals share information about their employer and to identify the differences between online and offline social networks. The use of SNSs depends on gender (Sander, Sloka \& Teh, 2016; McDonald et al., 2009). This paper compares the gender-influenced differences in using offline and online social networks.

\section{THEORETICAL FINDINGS}

Offline social networks are the communication forms among family and friends. Those networks have a high cohesion and high level of trust. The individuals have a history and experience with each other. Members of social networks exchange information, e.g. information about their employer if they meet each other. SNSs is a new kind of social network. In this article the authors use the definition by Boyd and Ellison (2007): Social network sites, SNSs, are web-based services that allow individuals to achieve the following: 1) to construct a public or semi-public profile within a bounded system; 2) to articulate a list of other users with whom they share a connection; 3 ) to view and traverse their list of connections and those made by others within the system".

SNSs are internet based networks to maintain and create relationships. Individuals have a profile and present their information about themselves, e.g. their current employer or company related information. This information is permanently available and shareable. The individuals can quickly and easily exchange information with friends globally and with broad audience (Wellman, 2001). Their information can be visible to many people including SNS members who are not in relationships with the individual. The difference between private and business SNSs is in their purpose. Private SNSs are mainly used for "leisure time", e.g. organising events. For example, one of the most popular private SNS is Facebook. Business SNSs are primarily used for "business" reasons, e.g. exchanging business relevant information. One of the most famous business SNS is LinkedIn (Zide, Elman \& Shahani-Denning, 2014). Individuals are members of social networks and they 
acquire an advantage by being members. The difference between online and offline social networks is the size. Online social networks can have millions of members world-wide. SNS can be used as a marketing tool, e.g. employer branding. Companies use SNS as a marketing tool to reach potential customers or candidates (Soares \& Pinho, 2014; Li \& Bernoff, 2011). Offline social networks are mainly regional and concentrated on a group with similar interests. The anonymity and privacy protection on SNSs is an important issue (Krasnova et al., 2009). Members do not know each other personally and cheating with SNS profiles is reported.

The social network has to provide a value or individuals would not join the network or leave the network (Ellison, Steinfield \& Lampe, 2007; McDonald, 2011). The value depends on the content of the social network and objective of the social network and the individual.

The social capital theory explains the exchange of information in social networks. Members of networks have access to beneficial information and resources. They invest in their network's resources, e.g. time or beneficial information for another member (Adler \& Kwon, 2002; Inkpen \& Tsang, 2005). For their investment they expect access to beneficial information. Individuals who misuse social networks can be penalized. The power of sanction increases the level of trust of members. Confidence is a major factor of networks and the exchange of resources and information. The name of the employer mentioned to a member of the social network can be a beneficial information. They can use the person who mentions the name as a reference or ask for further information from the individual who provided the name. The reputation of the company can be expanded on the person who provides the information to the network. There exist a transfer of reputation between the enterprise and the employee (Burt \& Panzarasa, 2012). It is an interesting reason for businesses to use the social capital of the individual to transfer their name to their network and to have the advantage.

The exchange of information about the employer is an important issue for companies. The companies are interested in transporting information to improve the employment-seeking process. The use of social networks to recruit employees is possible (Granovetter, 1995; Han \& Han, 2009). Many companies have an "employee recruits employees" program to use the employee networks to motivate candidates to apply. This self-fulfilled recruitment style operates by requiring the social network of the employee to display information regarding the employer's name. The assumption is, if an individual is satisfied with the employment the employee presents the name of the employer in online and offline social networks. People are proud of their employer, and they can increase their reputation by being employed by a popular company. They have a useful resource, information about the culture of the enterprise for example. The employee's investment is his sharing of knowledge. The employee expects to receive obligations in exchange for information. The obligations can be used to get needed or desired information to have an advantage (Kim, Lee \& Elias, 2015; The, Huah \& Si, 2014). That is a typical mechanism of how social networks operate.

This paper investigates the behaviour of individuals in forwarding the information about their network to other social network members. It is important for the companies to know if they can use different social networks as a tool to 
provide information via their employees to potential employees. They need new qualified employees and have a chance to communicate via social networks of their employees about the company. It means that the social network can forward employer branding relevant information.

The assumption is that there is a difference between online and offline networks because offline networks are more anonymous and are less trusted than online networks. The second assumption is that there is a significant difference between men and women regarding this topic. Previous evidence proves that women are more open to disclosure in online SNSs than men (Tufekci, 2008). The last assumption is that business and private SNSs are different although it is only regarding the mention of the name of the company.

\section{METHODOLOGY OF RESEARCH}

During the research scientific publications were reviewed in order to perform empirical analysis by the help of online survey. The respondents selected for the study were personally invited to fill in the survey, and it was ensured that each respondent participated in the survey only once. The results constitute the part of the questionnaire about the employment seeking topics. The questionnaire is a part of the research project at the University of Ludwigshafen. The empirical research used the results of a survey of 254 survey participants. All participants speak German. The online questionnaire was open in April 2016, and the respondents by personal invitation were invited to fill it in. By gender distribution of the respondents $30.1 \%$ were men and $69.9 \%$ were women. All participants had minimum a school degree and the majority of the participants had completed an apprenticeship. That means that $75.32 \%$ have experience with an employer. The questions regarding education and age were indicated by 231 participants - not all respondents out of 254 indicated their demographic information. They had the knowledge and chance to share information about their employer.

The age of the survey respondents was under 30. Those individuals were experienced with SNSs, and they had previous experience in the employmentseeking process and of being a member of social networks.

The Cronbach's alpha is 0.957 , and this is an indicator of excellent reliability. The research question "You are employed with a company, and you are very satisfied with this company. How important is it for you that other people are informed about your employment there?" has the evaluation opportunities for "family", "friends", "private SNSs, e.g. Facebook", and "business SNSs, e.g. LinkedIn or Xing". The evaluation scale has been from 1 for "very important" to 6 indicating "very unimportant".

The research was done using an online survey to collect from the participants their opinion about social networks and SNSs. The scale from one to six is similar to the evaluation scale of the German school grading and is easy to use for German individuals. 

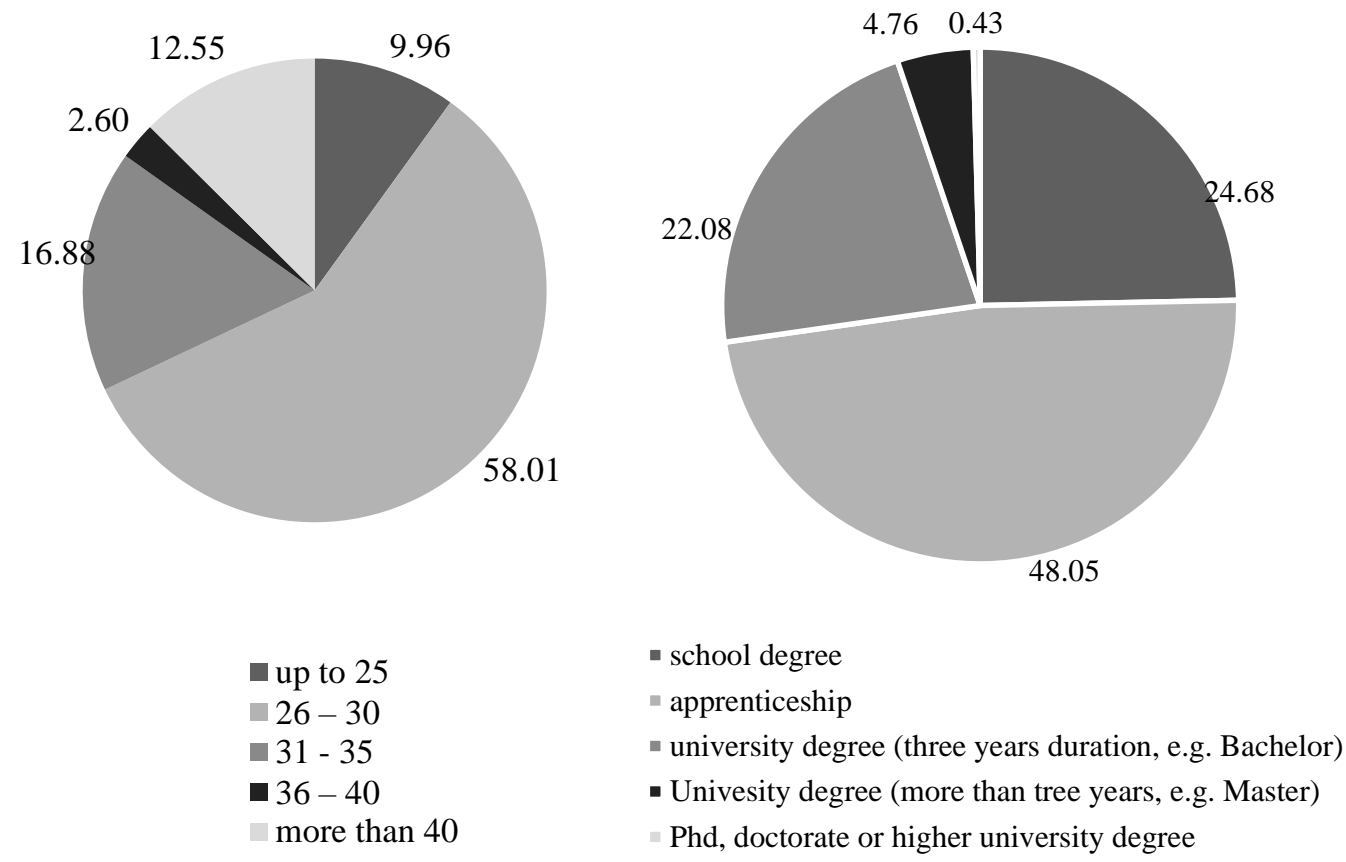

Fig. 1. Distribution of respondents by education and age, $n=231$ (Survey performed by Tom Sander, 2016)

The data obtained in the study has been analysed by the indicators of the central tendency or location: arithmetic mean, mode, median, as well as frequency, cross tables and t-test to investigate the gender differences.

\section{RESULTS}

The results from the answers to the question "You are employed by a company, and you are satisfied with your business. How important is it for you to inform other people about your employment there?" provide a clear picture. The information can be presented in online and offline networks. The offline networks are friends and family.

Both answers ("family" and "friends") have the median 2 and the tendency to "very important" is presented with the mode 1 and 2 for "family" and the mode 2 for "friends". The answer "family" has $69 \%$ of the evaluations in the first and second evaluation stage. The answer "friends" made $54 \%$ in the first and second stage. Online networks have a contrary picture. Online networks are business SNSs and private SNSs.

The median of the evaluations for private SNSs is 5 , and for business SNSs it is 4. Most of the respondents have evaluated both kinds of social networks with 6 (characterised by mode). The private SNSs have $59 \%$ cumulated in stage five and six. Business SNSs in the three last stages have cumulated $56 \%$. It means that the 
tendency is towards "very unimportant". The results are presented in detail in Fig. 2 and Table 1.

Table 1. Key Indicators of Central Tendency or Location on Respondent Evaluations of the Question "How important is it for you that other people are informed about your employment there?"

\begin{tabular}{|l|c|c|c|c|}
\hline & Family & Friends & Private SNS & Business SNS \\
\hline$n$ & 254 & 254 & 254 & 254 \\
\hline Mean & 1.52 & 1.89 & 3.72 & 3.11 \\
\hline Median & 2 & 2 & 5 & 4 \\
\hline Mode & 1 and 2 & 2 & 6 & 6 \\
\hline
\end{tabular}

Note. Evaluation scale $1-6$, where 1 - very important; 6 - very unimportant; $n=254$ (Survey conducted by Tom Sander, 2016).

The results provide clear differences between online and offline social networks. They also provide the type of online network differences. Business SNSs are more positively rated than private SNSs. The similarity is provided in "family" and "friends"; "family" is rated more positively than "friends". It means that the closeness of relationship influences the importance to provide the employment relevant information. The results are presented in Fig. 2 and provide a detailed information.

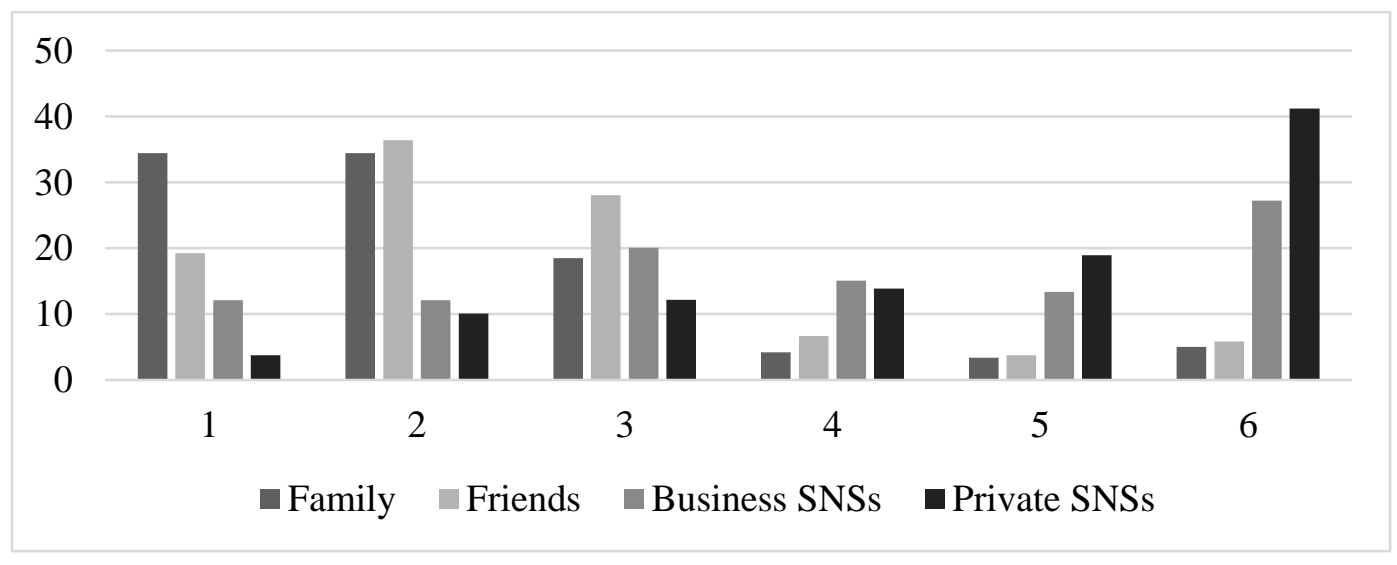

Fig. 2. Distribution of responses to the question "You are employed by a company, and you are very satisfied with this company. How important is it for you that other people are informed about your employment there?",

Note. Evaluation scale 1-6, where 1 - very important; 6 - very unimportant; $n=254$ (Survey conducted by Tom Sander, 2016).

The gender-influenced differences in using the online and offline networks can be seen in Fig. 2. Table 2 and Fig. 3 present the results divided into online SNSs and real social networks comparing men and women. The results of the cross table are presented in Table 2 . 
Table 2. Distribution of Evaluations of Online and Offline Networks by Gender to the Question "How important is it for you that other people are informed about your employment there?", Cross Table

\begin{tabular}{|c|c|c|c|c|}
\hline Scale & Women offline & Men offline & Women online & Men online \\
\hline 1 & 30.91 & 18.84 & 8.49 & 8.02 \\
\hline 2 & 34.38 & 39.13 & 12.26 & 8.75 \\
\hline 3 & 21.13 & 27.53 & 16.35 & 16.78 \\
\hline 4 & 5.67 & 4.34 & 14.46 & 13.13 \\
\hline 5 & 3.47 & 4.34 & 13.83 & 20.43 \\
\hline 6 & 4.41 & 5.79 & 34.59 & 32.84 \\
\hline
\end{tabular}

Note. Evaluation scale 1-6, where 1 - very important; 6 - very unimportant; Results in \%; $n=254$ (Survey conducted by Tom Sander, 2016).

The results for "women offline" are $65.29 \%$ in the first two stages and for "men offline" $57.97 \%$. The results clearly show that offline social networks are more important for the individuals under consideration for the employer. It is also evident that women agree more than men. Opposite results are presented for "men and women online" SNSs. "Men" have received $55.27 \%$ in the last two stages and $48.42 \%$ in the final two stages. The results are visualized in Fig. 3.

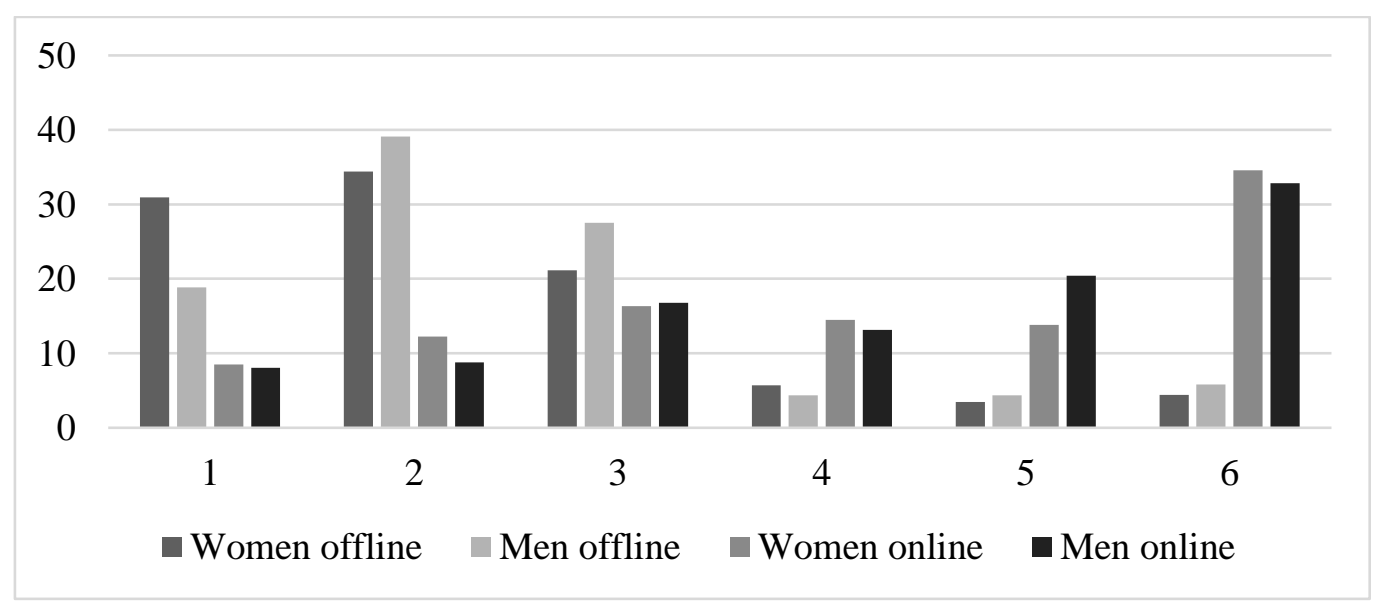

Fig. 3. Distribution of evaluations of online and offline networks by gender to the question "How important is it for you that other people are informed about your employment there?"

Note. Evaluation scale 1-6, where 1 - very important; 6 - very unimportant; $n=254$ (Survey conducted by Tom Sander, 2016).

Online social networks are business and private SNSs. Real networks are among family and friends. There exists a significant difference between men and women. The largest gap between men and women (12\% of points) is in the first stage of real networks.

In the third stage of the evaluation, there is a difference of $6 \%$ of points and in the second stage it is $4 \%$ of points between men and women. Men on the 
assessment scale have higher results in stage two and three. It means that the tendency of evaluation by women is more extreme for "very important" than for men in offline networks. There is a general tendency of online social networks being marked as "very unimportant". Only in the fifth stage of the evaluation scale there is a difference of $6 \%$ of points between men and women. It means that men and women give more homogeneous answers to "online networks" than "real networks". The results of t-test are presented in Table 3 .

Table 3. Analysis of Evaluations of Different Social Networks by Gender to the question "How important is it for you that other people are informed about your employment there?" with a t-test

\begin{tabular}{|c|c|c|c|c|c|c|c|c|c|c|}
\hline \multicolumn{11}{|c|}{ Independent Samples Test } \\
\hline & & \multicolumn{2}{|c|}{$\begin{array}{c}\text { Levene's Test } \\
\text { for Equality } \\
\text { of Variances }\end{array}$} & \multicolumn{7}{|c|}{ t-test for Equality of Means } \\
\hline & & \multirow[b]{2}{*}{$\mathrm{F}$} & \multirow[b]{2}{*}{ Sig. } & \multirow[b]{2}{*}{$\mathrm{t}$} & \multirow[b]{2}{*}{ Df } & \multirow{2}{*}{$\begin{array}{l}\text { Sig. (2- } \\
\text { tailed) }\end{array}$} & \multirow{2}{*}{$\begin{array}{l}\text { Mean } \\
\text { Diffe- } \\
\text { rence }\end{array}$} & \multirow{2}{*}{$\begin{array}{l}\text { Std. } \\
\text { Error } \\
\text { Diffe- } \\
\text { rence }\end{array}$} & \multicolumn{2}{|c|}{$\begin{array}{l}95 \% \text { Confidence } \\
\text { Interval of the } \\
\text { Difference }\end{array}$} \\
\hline & & & & & & & & & Lower & Upper \\
\hline \multirow[t]{2}{*}{ Family } & $\begin{array}{c}\text { Equal } \\
\text { variances } \\
\text { assumed }\end{array}$ & 0.03 & 0.84 & 1.812 & 227 & 0.071 & 0.431 & 0.238 & -0.03 & 0.899 \\
\hline & $\begin{array}{c}\text { Equal } \\
\text { variances } \\
\text { not } \\
\text { assumed }\end{array}$ & & & 2.032 & 171 & 0.044 & 0.431 & 0.212 & 0.012 & 0.849 \\
\hline \multirow[t]{2}{*}{ Friends } & $\begin{array}{c}\text { Equal } \\
\text { variances } \\
\text { assumed }\end{array}$ & 0.45 & 0.50 & 1.211 & 227 & 0.227 & 0.260 & 0.215 & -0.16 & 0.684 \\
\hline & $\begin{array}{c}\text { Equal } \\
\text { variances } \\
\text { not } \\
\text { assumed }\end{array}$ & & & 1.321 & 159 & 0.189 & 0.260 & 0.197 & -0.12 & 0.650 \\
\hline \multirow[t]{2}{*}{$\begin{array}{c}\text { Private } \\
\text { SNS }\end{array}$} & $\begin{array}{c}\text { Equal } \\
\text { variances } \\
\text { assumed }\end{array}$ & 0.65 & 0.42 & -0.70 & 227 & 0.484 & -0.202 & 0.288 & -0.76 & 0.365 \\
\hline & $\begin{array}{c}\text { Equal } \\
\text { variances } \\
\text { not } \\
\text { assumed }\end{array}$ & & & -0.64 & 109 & 0.519 & -0.202 & 0.312 & -0.82 & 0.416 \\
\hline \multirow[t]{2}{*}{$\begin{array}{c}\text { Business } \\
\text { SNS }\end{array}$} & $\begin{array}{c}\text { Equal } \\
\text { variances } \\
\text { assumed }\end{array}$ & 1.54 & 0.21 & 1.421 & 227 & 0.157 & 0.395 & 0.278 & -0.15 & 0.944 \\
\hline & $\begin{array}{c}\text { Equal } \\
\text { variances } \\
\text { not } \\
\text { assumed }\end{array}$ & & & 1.544 & 158 & 0.125 & 0.395 & 0.256 & -0.11 & 0.901 \\
\hline
\end{tabular}

Note. Evaluation scale 1-6, where 1 - very important; 6 - very unimportant; $n=254$ (Survey conducted by Tom Sander, 2016).

The result of the t-test regarding the significance does not confirm that there is a difference between men and women. 


\section{CONCLUSION}

The motivation of individuals to mention their employer in social networks depends on the kind of the social network. Online social networks compared with real social networks provide information that people do not use online social networks, e.g. private or business SNSs, to transfer or represent the name of their employer. It is not important to mention the employer in those networks. Private and business SNSs were compared to provide the proof that the participants mainly avoid using private SNSs to represent their company. It is not important for them.

Men and women are different in the use of social networks. More women than men have the opinion that it is more important to use offline networks to transfer the employer's name. The differences of SNSs are homogeneous. However, men perceive mentioning of the employer's name as less important than the perception displayed by women. It means that women have higher evaluations for both kinds of network. Women more often than men confirm that it is more important to present the employer in online and offline social networks.

Companies need to evaluate the reasons why their employees use real networks to exchange the name of the employer, but not SNSs. SNSs are a great tool with the potential to motivate and to inform individuals about companies. The relationship can be used to transfer more information and the relationship with individuals can increase trust for other persons. Human resource management needs new tools to inform potential candidates about their attractive offers to potential employees. Communication in social networks reduces the transaction costs, is more trustful and faster. It means that companies and their employees have many opportunities to use SNSs to be more successful in their recruiting process.

The assumptions have been confirmed. There are differences between genders, kinds of network and purpose of network. It means that every network is different and it is difficult to use all networks in the same way. Companies have to research networks, creating a tailor-made strategy for the network and have to take into consideration the objective - which individual should be reached. Social networks are too various and have to be explored to know if they are useful and fruitful for the company.

The limitation of the paper is the gender distribution which needs further research. The reasons not to use or to use SNSs to mention the employer's name in those networks need more explanations which can be used by companies to encourage their employees to transfer a positive picture about the company and its products.

\section{REFERENCES}

Adler, P. S., \& Kwon, S.-W. (2002). Social capital: Prospects for a new concept. Academy of Management Review, 27(1), 17-40. https://doi.org/10.5465/amr.2002.5922314

Backhaus, K., \& Tikoo, S. (2004). Conceptualizing and researching employer branding. Career Development International, 9(5), 501-517. http://dx.doi.org/10.1108/13620430410550754

Boyd, D. M., \& Ellison, N. B. (2007). Social Network Sites: Definition, History, and Scholarship. Journal of Computer-Mediated Communication, 13(1), 210-230. https://doi.org/10.1111/j.10836101.2007.00393.x 
Brecht, F., Koroleva, K., \& Guenther, O. (2011). Increasing Global Reach: Using Social Network Sites for Employer Branding. Wirtschaftinformatik Proceedings. Paper 17. Retrieved from http://aisel.aisnet.org/wi2011/17

Burt, R., \& Panzarasa, P. (2012). Gossip and reputation. In L. L. Thompson, J. M. Levine, \& D. M. Messick (Eds.), Shared Cognition in Organizations: The Management of Knowledge (pp. 2742). New York, USA: Psychology Press.

Caers, R., \& Castelyns, V. (2011). LinkedIn and Facebook in Belgium: The Influences and Biases of Social Network Sites in Recruitment and Selection Procedures. Social Science Computer Review, 29(4), 437-448. https://doi.org/10.1177/0894439310386567

Collins, C. J., \& Stevens, C. K. (2002). The Relationship Between Early Recruitment-Related Activities and the Application Decisions of New Labor-Market Entrants: A Brand Equity Approach to Recruitment. Journal of Applied Psychology, 87(6), 1121-1133. https://doi.org/10.1037/0021-9010.87.6.1121

Davison, H. K., Maraist, C., \& Bing, M. N. (2011). Friend or Foe? The Promise and Pitfalls of Using Social Networking Sites for HR Decisions. Journal of Business and Psychology, 26(2), 153159. https://doi.org/10.1007/s10869-011-9215-8

Ellison, N. B., Steinfield, C., \& Lampe, C. (2007). The benefits of facebook “friends:” Social capital and college students'use of online social network sites. Journal of Computer Mediated Communication, 12, 1143-1168. https://doi.org/10.1111/j.1083-6101.2007.00367.x

German Bureau of Statistics Report. (2015). Retrieved from https://www.destatis.de/DE/Publikationen/Thematisch/EinkommenKonsumLebensbedingunge n/PrivateHaushalte/PrivateHaushalteIKT2150400157004.pdf?_blob=publicationFile

Granovetter, M. S. (1995). Getting a job. A Study or Contracts and Careers (2nd ed.). Chicago: The university of Chicago press.

Han, J., \& Han, J. (2009). Network-based recruiting and applicant attraction in China: insights from both organizational and individual perspectives. The International Journal of Human Resource Management, 20(11), 2228-2249. http://doi.org/10.1080/09585190903239633

Inkpen, A., \& Tsang, E. W. K. (2005). Social capital, networks, and knowledge transfer. The Academy of Management Review, 30(1), 146-165. https://doi.org/10.5465/AMR.2005.15281445

Kim, J., Lee, C., \& Elias, T. (2015). Factors affecting information sharing in social networking sites amongst university students. Online Information Review, 39(3), 290-309. https://doi.org/10.1108/OIR-01-2015-0022

Krasnova, H., Günter, O., Spiekerman, S., \& Koroleva, K. (2009). Privacy concerns and identity in online social networks. Identity in the Information Society, 2(1), 39-63. https://doi.org/10.1007/s12394-009-0019-1

Li, C., \& Bernoff, J. (2011). Groundswell, winning in a world transformed by social technologies, Boston: Harvard Business Review Press.

McDonald, S. (2011). What's in the "old boys" network? Accessing social capital in gendered and $\begin{array}{lllll}\text { racialized networks. } & \text { Social } & \text { Networks, } & 33(4), & 330 .\end{array}$ https://doi.org/10.1016/j.socnet.2011.10.002

McDonald, S., Lin, N., \& Ao, D. (2009). Networks of Opportunity: Gender, Race, and Job Leads. Social Problems, 56(3), 385-402. https://doi.org/10.1525/sp.2009.56.3.385

Research by digital agency 'Click'. (2012). Retrieved from http://www.lsm.lv/lv/raksts/latvija/zinas/petiijuma-noskaidrots-socialo-tiiklu-lietojumslatvija.a27372/

Sander, T., Sloka, B., \& Pauzuoliene, J. (2015). The Difference of Social Network Sites Explained with the Employment Seeking Process. Regional Formation and Development Studies, 3(17), 145-153.

Sander, T., Sloka, B., \& Teh, P. L. (2016). Gender Difference in the use of Social Network Sites. In Project Management Development - Practice and Perspectives. 324-332.

Soares, M., \& Pinho, C. J. (2014). Advertising in online social networks: the role of perceived enjoyment and social influence. Journal of Research in Interactive Marketing, 8(3), 245-263. https://doi.org/10.1108/JRIM-08-2014-001

Teh, P.-L., Huah, L. P., \& Si, Y.-W. (2014). The Intention to Share and Re-Shared among the Young 
Adults towards a Posting at social Networkin Sites. In A. Rocha et al., (Eds.). New Perspectives in Information Systems and Technologies. Heidelberg: Springer Berlin Heidelberg, 13-21. https://doi.org/10.1007/978-3-319-05951-8_2

Tufekci, Z. (2008). Can you see me now? Audience and disclosure regulation in online social network sites. Bulletin of the American Society for Information Science and Technology, 28(1), 20-36. https://doi.org/10.1177/0270467607311484

Wellman, B. (2001). Computer Networks as social Networks. Computer and Science, 293(5537), 2031-2034. https://doi.org/10.1126/science.1065547

Weitzel, T. Eckhardt, A., Laumer, S., Maier, C., von Stetten, \& A., Weinert, C. (2014). Bewerbungspraxis 2014 - Eine empirische Studie mit über 10000 Stellensuchennden und Karriereinteressierten im Internet, Frankfurt am Main.

Zide, J., Elman, B., \& Shahani-Denning, C. (2014). LinkedIn and recruitment: how profiles differ across occupations. Employee Relations, 36(5), 583-604. https://doi.org/10.1108/ER-07-2013$\underline{0086}$

\section{AUTHORS' SHORT BIOGRAPHY}

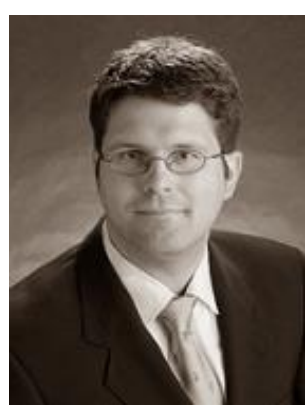

Tom Sander obtained the Business Administration diploma from Europa Fachhochschule Fresenius (University of Applied sciences) in 2007, and received the MBA from Europäische Fernhochschule Hamburg (University of Applied Sciences) in 2010. From 2011-2016, he was a doctoral student with the University of Latvia. He gives lectures on Strategic Human Resource Management and Employer Branding/recruiting at the Hochschule Ludwigshafen. His research topic is social networks under consideration of new technologies and recruiting issues. He is currently working as a Recruiter for Riverbed in Karlsruhe and has more than 10 years of experience as a recruiter.

E-mail: tom.sander@riverbed.com

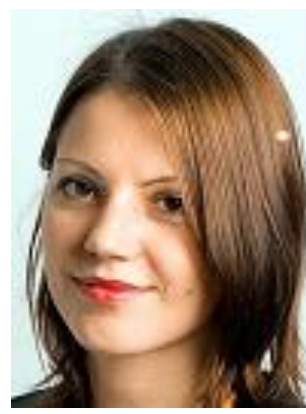

Ieva Pūḳe obtained the Business Administration diploma in 2002 and the MBA degree in International Business in 2005 from the Faculty of Economics and Management, the University of Latvia. Since 2015, she has been a doctoral student with the University of Latvia. Her research topic is export marketing of new international ventures. She is a Lecturer with the BA School of Business and Finance in Riga, Latvia. She has 10 years of experience in marketing management and is currently a Strategic Marketing Consultant with Rise Marketing Ltd.

E-mail: ieva.puuke@gmail.com

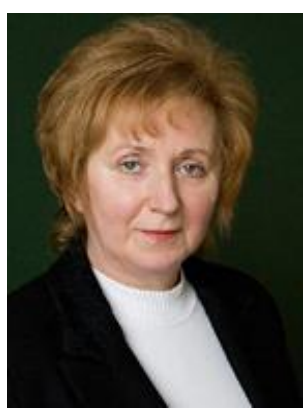

Biruta Sloka, Dr. oec., is a Professor with the University of Latvia. She has participated in several research projects. She is Head of the Euro Faculty Riga Centre. She is a Member of the Latvian Association of Econometrists, Member of Association of Professors of Higher Education of Latvia and the President of the Latvian Association of Statisticians.

Address: Faculty of Economics and Management, University of Latvia, 5 Aspazijas Blvd., Riga, LV-1050, Latvia

Phone: +371 29244966,

E-mail: Biruta.Sloka@lu.lv 